\title{
FAKTOR-FAKTOR YANG BERHUBUNGAN DENGAN PENGETAHUAN KADER POSYANDU TENTANG GOLDEN PERIOD PADA ANAK BATITA DI POSYANDU DESA GARAJATI KECAMATAN CIWARU 2021
}

\author{
Dinda Nur Azizah, Dewi Laelatul Badriah, Nova Winda Setiati \\ STIKes Kuningan \\ ndindazizah@gmail.com
}

\begin{abstract}
Abstrak
Golden Period adalah masa disaat otak bayi mengalami perkembangan yang paling cepat. Kader sebagai salah satu ujung tombak kesehatan masyarakat di Desa bertugas menjadi jembatan antara masyarakat dengan petugas kesehatan, harus memiliki pengetahuan tentang kesehatan salah satunya tentang Golden Period pada tumbuh kembang anak batita. Hasil studi pendahuluan dari 5 orang kader terdapat 3 orang yang belum mendapat informasi khusus tentang golden period, 2 kader berpendidikan SMP dan 1 orang berpendidikan SMA yang semuanya berusia lebih dari 35 tahun. Tujuan penelitian ini untuk mengidentifikasi faktorfaktor yang berhubungan dengan pengetahuan kader tentang golden period.

Jenis penelitian yang digunakan adalah analitik desain korelasional. Populasi penelitian ini adalah semua kader posyandu Desa Garajati sebanyak 30 orang dengan teknik total sampling, instrumen yang digunakan adalah kuesioner. Rancangan analisis data yang digunakan adalah analisis univariat dan analisis bivariat dengan uji statistik rank spearman.

Kader sebagian besar berpendidikan SLTA/SMA 16 orang (53,3\%), sebagian besar kader berusia diatas 35 tahun 24 orang $(80,0 \%)$, sebagian besar kader mendapatkan informasi dari media elektronik sebanyak 19 orang $(63,3 \%)$, Hasil penelitian ini terdapat hubungan antara pendidikan dengan pengetahuan kader dengan nilai koefisien korelasi 0,692. Tidak terdapat hubungan antara usia dengan pengetahuan karena nilai koefisien korelasi 0,102 yang berarti tidak ada korelasi antara usia dan pengetahuan. Terdapat hubungan antara sumber informasi dengan pengetahuan kader posyandu dengan nilai koefisien korelasi 0,396.

Kader Posyandu diharapkan lebih antusias dalam mencari informasi tentang Golden Period pada tumbuh kembang anak batita sehingga dapat meningkatkan pengetahuan kader tentang Golden Period pada anak batita.
\end{abstract}


Kata Kunci : Golden period, Kader Posyandu, Pendidikan, Usia, Sumber Informasi, Pengetahuan

\section{Pendahuluan}

Anak adalah aset yang berharga bagi suatu negara, oleh karena itu masa anak-anak dikenal dengan "masa emas" (golden period). Sebanyak 200 juta anak balita di negara berkembang lebih dari sepertiganya tidak terpenuhi potensinya untuk perkembangan. Hal tersebut diperkirakan akan mengakibatkan penghasilan anak di masa dewasa berkurang sebesar $20 \%$ sehingga akan berpengaruh pada perkembangan nasional suatu bangsa (Moonik et al., 2015). Golden Period merupakan masa paling kritis pada pertumbuhan dan perkembangan anak. Masalah pada tumbuh kembang anak diantaranya adalah anak kurus (wasting), bertubuh pendek (stunting), kegemukan (obesitas), dan anemia.

\section{Menteri Koordinator Bidang}

Pembangunan Manusia dan Kebudayaan (Menko PMK), Muhadjir Effendy, menegaskan bahwa upaya untuk menurunkan angka stunting di Indonesia harus mencapai target $14 \%$ pada tahun 2024 atau dibawah 680 ribu per tahun (Rohmah \& Arifah, 2021). Berdasarkan data dari Puskesmas Ciwaru pada bulan Agustus
2019 didapatkan dari hasil 2420 balita yang telah dilakukan pengukuran antropometri, total 90 balita stunting, 129 balita wasting, dan 125 balita dengan permasalahan gizi buruk dan gizi kurang. Pada Januari 2021 di Posyandu dusun Kliwon Desa Garajati terdapat 3 orang batita dengan gizi buruk dan 2 orang batita dengan gangguan keterlambatan berbicara. Peneliti menyimpulkan bahwa masih banyak terdapat permasalahan tumbuh kembang balita di Kecamatan Ciwaru, kondisi ini erat kaitannya dengan pemantauan pertumbuhan dan perkembangan di posyandu, kader Posyandu bersama Bidan Desa berperan dalam pelaksanaan pelayanan kesehatan khususnya kegiatan posyandu. Studi pendahuluan yang dilakukan oleh peneliti pada tanggal 24 November 2020 di Desa Garajati diketahui kader berjumlah 30 orang. Hasil wawancara dengan 5 orang kader, yang semuanya berusia diatas 30 tahun didapatkan dari 5 kader tersebut 3 kader masih belum pernah mendapat informasi khusus tentang Golden Period pada masa tumbuh kembang anak karena sumber informasi dan pendidikan 
yang masih terbatas, diantara 5 kader berpendidikan 2 orang SMA, 2 orang SMP dan 1 orang Sarjana. Hasil wawancara dengan Bidan Koordinator Puskesmas Ciwaru didapatkan bahwa kader posyandu setiap Desa di kecamatan Ciwaru seluruhnya aktif namun yang membedakan

\section{Metode}

Jenis penelitian yang digunakan adalah analitik desain korelasional. Dilakukan di Posyandu Desa Garajati Kecamatan Ciwaru pada bulan maret tahun 2021. Populasi penelitian ini adalah semua kader posyandu Desa Garajati sebanyak 30

\section{Hasil}

1. Analisis Univariat

Berdasarkan hasil penelitian yang dilakukan di Posyandu Desa Garajati Kecamatan Ciwaru Kabupaten Kuningan adalah tingkat partisipasi terhadap kegiatan posyandu di tiap desa, masih ada desa yang kader nya tidak semua kompak dalam kegiatan seperti pelatihan dan pembinaan kader. Kader Posyandu yang dinilai paling aktif adalah Desa Lebakherang.

orang dengan teknik total sampling, instrumen yang digunakan adalah kuesioner. Rancangan analisis data yang digunakan adalah analisis univariat dan analisis bivariat dengan uji statistik rank spearman.

tentang faktor- faktor yang mempengaruhi pengetahuan kader posyandu tentang Golden Period pada anak Batita, maka didapatkan hasil sebagai berikut:

Tabel 1 Distribusi Frekuensi Pendidikan, Usia, Sumber Informasi dan Pengetahuan Kader Posyandu di Desa Garajati Kecamatan Ciwaru Tahun 2021.

\begin{tabular}{lcc}
\hline \multicolumn{1}{c}{ Variabel } & Frekuensi & Presentase (\%) \\
\hline \multicolumn{1}{c}{ Total } & 30 & 100 \\
\hline Pendidikan & & \\
Dasar & 12 & 40.0 \\
Menengah & 16 & 53.3 \\
Perguruan Tinggi & 2 & 6.7 \\
\hline Usia & 1 & 3.3 \\
$\leq 20$ tahun & 5 & 16.7 \\
$21-35$ tahun & 24 & 80.0 \\
$\geq 35$ tahun & &
\end{tabular}




\begin{tabular}{lcc}
\hline Media Cetak & 11 & 36.7 \\
Media Elektronik & 19 & 63.3 \\
\hline Pengetahuan & & \\
Baik & 3 & 10.0 \\
Cukup & 15 & 50.0 \\
Kurang & 12 & 40.0 \\
\hline
\end{tabular}

Berdasarkan tabel 1 menunjukkan bahwa dari 30 orang responden sebagian besar berpendidikan menengah yaitu SLTA/SMA sebanyak 16 orang $(53,3 \%)$, dan responden yang berusia diatas 35 tahun sebanyak $24(80,0 \%)$, tahun, dan sebagian besar kader mendapatkan informasi dari media elektronik sebanyak 19 orang $(63,3 \%)$, responden yang memiliki pengetahuan cukup yaitu sebanyak 15 orang $(50,0 \%)$.

\section{Analisis Bivariat}

Untuk mengetahui hubungan antara dengan ketentuan jika nilai $\mathrm{p}$ value $<0.05$ variabel bebas terhadap variabel terikat, maka terdapat hubungan atau dan hipotesis maka penulis melakukan analisis variabel diterima.

a. Hubungan Faktor Pendidikan dengan Pengetahuan Kader

Tabel 2. Hubungan Faktor Pendidikan dengan Pengetahuan Kader di Posyandu Desa Garajati Kecamatan Ciwaru Tahun 2021.

\begin{tabular}{|c|c|c|c|c|c|c|c|c|c|c|}
\hline \multirow{3}{*}{ Pendidikan } & \multicolumn{6}{|c|}{ Pengetahuan } & \multirow{2}{*}{\multicolumn{2}{|c|}{ Total }} & \multirow{3}{*}{ P-Value } & \multirow{3}{*}{ OR } \\
\hline & \multicolumn{2}{|c|}{ Baik } & \multicolumn{2}{|c|}{ Cukup } & \multicolumn{2}{|c|}{ Kurang } & & & & \\
\hline & $\mathbf{F}$ & $\%$ & $\mathbf{F}$ & $\%$ & $\mathbf{F}$ & $\%$ & $\mathbf{F}$ & $\%$ & & \\
\hline Dasar & 0 & 0.0 & 3 & 25.0 & 9 & 75.0 & 12 & 100 & & \\
\hline Menengah & 1 & 6.3 & 12 & 75.0 & 3 & 18.8 & 16 & 100 & 0.692 & 0.000 \\
\hline Perguruan Tinggi & 2 & 100.0 & 0 & 0.0 & 0 & 0.0 & 2 & 100 & & \\
\hline
\end{tabular}

Sumber : Hasil Penelitian 2021.

Berdasarkan tabel 2 dari 16 berarti korelasi yang terjadi antara responden yang berpendidikan menengah pendidikan dan pengetahuan sangat kuat. mayoritas memiliki pengetahuan cukup Angka $\quad 0,000 \quad$ menunjukan tingkat sebanyak 12 orang $(75,0 \%)$. Berdasarkan uji Spearman Rank diperoleh p-value 0,692 signifikansi, karena tingkat signifikansi lebih kecil dari 0,05 dengan arah positif 
sehingga korelasi antara pendidikan dan pengetahuan positif dan signifikan.

b. Hubungan Faktor Usia dengan Pengetahuan Kader

Tabel 3. Hubungan Faktor Usia dengan Pengetahuan Kader di Posyandu Desa Garajati Kecamatan Ciwaru Tahun 2021.

\begin{tabular}{|c|c|c|c|c|c|c|c|c|c|c|}
\hline \multirow{3}{*}{ Usia } & \multicolumn{6}{|c|}{ Pengetahuan } & \multirow{2}{*}{\multicolumn{2}{|c|}{ Total }} & \multirow{3}{*}{ P-value } & \multirow{3}{*}{$O R$} \\
\hline & \multicolumn{2}{|c|}{ Baik } & \multicolumn{2}{|c|}{ Cukup } & \multicolumn{2}{|c|}{ Kurang } & & & & \\
\hline & $\mathbf{F}$ & $\%$ & $\mathbf{F}$ & $\%$ & $\mathbf{F}$ & $\%$ & $\mathbf{F}$ & $\%$ & & \\
\hline $\begin{array}{l}\leq 20 \\
\text { tahun }\end{array}$ & 0 & 0.0 & 0 & 0.0 & 1 & 10.0 & 1 & 100 & & \\
\hline $\begin{array}{l}21-35 \\
\text { tahun }\end{array}$ & 0 & 0.0 & 4 & 80.0 & 1 & 20.0 & 5 & 100 & 0,102 & 0,591 \\
\hline $\begin{array}{l}\geq 35 \\
\text { tahun }\end{array}$ & 3 & 10.0 & 11 & 45.8 & 10 & 41.7 & 24 & 100 & & \\
\hline
\end{tabular}

Berdasarkan tabel 3 dari 24 Spearman Rank diperoleh p-value 0,012 responden yang berusia diatas 35 tahun berarti tidak ada korelasi antara usia dan mayoritas memiliki pengetahuan cukup pengetahuan. sebanyak 11 orang $(45,8 \%)$. Hasil uji

c. Hubungan Faktor Sumber Informasi dengan Pengetahuan Kader

Tabel 4. Hubungan Faktor Sumber Informasi dengan Pengetahuan Kader di Posyandu Desa Garajati Kecamatan Ciwaru Tahun 2021.

\begin{tabular}{|c|c|c|c|c|c|c|c|c|c|c|}
\hline \multirow{3}{*}{ Sumber Informasi } & \multicolumn{6}{|c|}{ Pengetahuan } & \multirow{2}{*}{\multicolumn{2}{|c|}{ Total }} & \multirow{3}{*}{ P-Value } & \multirow{3}{*}{ OR } \\
\hline & \multicolumn{2}{|c|}{ Baik } & \multicolumn{2}{|c|}{ Cukup } & \multicolumn{2}{|c|}{ Kurang } & & & & \\
\hline & $\mathrm{F}$ & $\%$ & $\mathrm{~F}$ & $\%$ & $\mathrm{~F}$ & $\%$ & $\mathrm{~F}$ & $\%$ & & \\
\hline Media Cetak & 1 & 9,1 & 5 & 45,5 & 5 & 45,5 & 11 & 100 & \multirow{2}{*}{0,396} & \multirow{2}{*}{0,030} \\
\hline Media Elektronik & 2 & 10,5 & 10 & 52,6 & 7 & 36,8 & 19 & 100 & & \\
\hline
\end{tabular}

Berdasarkan tabel 4 dari 19 uji Spearman Rank diperoleh nilai koefisien responden yang yang mendapat informasi korelasi 0,396 berarti korelasi yang terjadi Golden Period melalui media elektronik antara sumber informasi dan pengetahuan mayoritas memiliki pengetahuan cukup dalam tingkat cukup. Angka 0,030 sebanyak 10 orang $(52,6 \%)$. Berdasarkan menunjukan tingkat signifikansi, karena 
JOURNAL OF MIDWIFERY CARE :

VOL. 02 No. 01, DESEMBER 2021

DOI: $10.34305 / \mathrm{JMC} . \mathrm{V} 2 \mathrm{I} 01.352$

tingkat signifikansi lebih kecil dari 0,05 dengan arah positif sehingga korelasi antara

\section{Pembahasan}

Berdasarkan analisis yang telah dilakukan oleh peneliti di Posyandu Desa Garajati Kecamatan Ciwaru tahun 2021 bahwa sebagian besar kader posyandu yang memiliki pengetahuan cukup tentang Golden Period pada anak Batita adalah yang memiliki pendidikan menengah yaitu SLTA/SMA berjumlah 12 responden (75,0\%). Dalam penelitian ini semakin tinggi pendidikan responden maka mempengaruhi tingkat pengetahuan tentang Golden Period pada anak batita, dari 12 orang yang berpendidikan dasar terdapat 9 orang yang berpengetahuan kurang, Adanya hubungan antara tingkat pendidikan dengan pengetahuan tentang Golden Period disebabkan karena tingkat pendidikan merupakan salah satu faktor yang dapat mempengaruhi tingkat pengetahuan seseorang, hal ini sesuai dengan teori pendidikan dan pengetahuan positif dan signifikan. menurut (Notoatmodjo et al., 2012), pendidikan merupakan suatu sebuah upaya atau usaha untuk memperluas perkembangan kemampuan maupun kepribadian yang bisa didapat melalui pendidikan formal maupun non formal yang berlangsung seumur hidup.

Menurut (Himmawan, 2020), kader merupakan pekerjaan sukarela, yang bekerja mengabdi kepada masyarakat, dan untuk menjadi seorang kader tidak memiliki syarat harus berpendidikan tinggi sehingga kader memiliki pendidikan yang beragam, oleh karena itu, penyuluhan atau refresh pengetahuan dengan cara berkala mengenai pengetahuan bagi kader Posyandu terutama tentang Golden Period pada tumbuh kembang anak batita perlu dilakukan untuk mengoptimalkan kinerja kader. 
JOURNAL OF MIDWIFERY CARE :

VOL. 02 NO. 01, DESEMBER 2021

DOI: $10.34305 / \mathrm{JMC} . \mathrm{V} 2 \mathrm{I} 01.352$

Penelitian ini didukung oleh Garajati Kecamatan Ciwaru Tahun 2021

penelitian (Himmawan, 2020) yang menyatakan bahwa variabel usia tidak ada hubungannya dengan pengetahuan tentang Golden Period pada anak batita. Sejalan dengan teori yang dikemukakan (Himmawan, 2020), bahwa seorang kader akan tetap menjadi kader sampai memutuskan untuk berhenti, karena tidak ada peraturan yang menyebutkan mengenai batasan masa kerja dan usia untuk menjadi kader, sehingga banyak kader yang sudah berusia tua namun tetap menjadi seorang kader. Hal ini terjadi karena kemungkinan pengetahuan yang ia miliki bisa saja berasal dari pengetahuan yang dimilikinya sebelumnya, pengalaman pribadi maupun orang lain dan beberapa faktor lainnya yang dapat membentuk pengetahuan seseorang dalam jangka waktu yang lama dan akan bertahan sampai usia tua.

Berdasarkan analisis peneliti mayoritas responden di Posyandu Desa mayoritas mendapat informasi Golden Period dengan media elektronik yaitu sebanyak 19 responden $(63,3 \%)$, sehingga media elektronik berperan dalam memberikan informasi tentang Golden Period pada tumbuh kembang anak batita. Mayoritas responden mendapat informasi dari media elektronik dibandingkan dengan media cetak. Hal ini disebabkan responden lebih banyak mengakses media elektronik seperti televisi, radio maupun internet di kesehariannya.

Televisi, radio dan internet merupakan media elektronik yang dapat dikatakan sebagai media komunikasi yang dapat dengan mudah diakses, sehingga kader posyandu dapat mengakses kapan saja. Sumber informasi dapat diperoleh melalui media cetak dan media elektronik.

Berdasarkan analisis penelitian mayoritas responden di Posyandu Desa Garajati dari 30 responden sebagian besar 
JOURNAL OF MIDWIFERY CARE :

VOL. 02 No. 01, DESEMBER 2021

DOI: $10.34305 / \mathrm{JMC} . \mathrm{V} 2 \mathrm{I} 01.352$

mendapat informasi tentang Golden Period dengan media elektronik yang didapatkan langsung dari internet melalui media sosial seperti youtube, google, dan whatsapp. Aplikasi tersebut dilengkapi gambar dan video sehingga pesan atau isi materi yang disampaikan mudah dipahami. Aplikasi whatsapp merupakan aplikasi pesan paling populer. Kader Posyandu Desa Garajati sendiri memiliki Grup whatsapp yang beranggotakan Bidan Desa dan seluruh kader posyandu. Whatsapp grup kader posyandu berperan sebagai wadah berdiskusi ataupun bertukar informasi

\section{Kesimpulan}

1. Sebagian besar kader berpendidikan SLTA/SMA dengan tingkat pengetahuan cukup sebanyak 12 orang $(75,0 \%)$.

2. Sebagian besar kader posyandu berusia diatas 35 tahun dengan tingkat pengetahuan cukup sebanyak 11 orang $(45,8 \%)$ antara Bidan dengan kader posyandu, bidan mengedukasi kader posyandu dengan cara membagikan materi atau informasi dalam bentuk foto, video, dsb. Hasil survey (Kusumadewi et al., 2019) juga menunjukkan bahwa $83 \%$ kader posyandu menggunakan smartphone untuk menjalankan aplikasi whatsapp dan 19\% untuk menjalankan media sosial. Dalam penelitian ini tertera bahwa sumber informasi media elektronik lebih jelas dan dapat diterima karena mudah diakses oleh setiap kader posyandu.

3. Sebagian besar pengetahuan kader posyandu bersumber dari media elektronik dengan tingkat pengetahuan cukup sebanyak 10 orang $(52,6 \%)$.

4. Ada hubungan antara pendidikan dan pengetahuan diperoleh dari nilai koefisien korelasi 0,692. 
JOURNAL OF MIDWIFERY CARE :

VOL. 02 No. 01, DESEMBER 2021

DOI: $10.34305 / \mathrm{JMC} . \mathrm{V} 2 \mathrm{I} 01.352$
Ciptaan disebarluaskan di bawah

Lisensi Creative Commons

Atribusi-NonKomersial

BerbagiSerupa 4.0 Internasional
5. Tidak ada hubungan antara pengetahuan dan usia diperoleh dari nilai koefisien korelasi 0,012.

6. Ada hubungan antara sumber informasi dengan pengetahuan kader posyandu diperoleh dari nilai koefisien korelasi 0,396.

\section{Saran}

1. Bagi Kader

Diharapkan kader bisa lebih meningkatkan pengetahuan tentang Golden Period pada tumbuh kembang anak batita yang bertujuan untuk ikut memantau dan mendampingi tumbuh kembang anak dalam masa usia Golden Period 0-3 tahun, dan kader posyandu diharapkan lebih antusias

\section{Daftar Pustaka}

Himmawan, L. S. (2020). Faktor Yang Berhubungan Dengan Pengetahuan Kader Posyandu Tentang 1000 Hari Pertama Kehidupan (Hpk). Jurnal Kesehatan, 11(1), 23-30.

Kusumadewi, S., Kurniawan, R., \& Wahyuningsih, H. (2019). Implementasi Sistem Informasi Posyandu Berbasis Web Dan Android Di Desa Bimomartani. Jppm (Jurnal dalam mencari informasi tentang Golden Period pada tumbuh kembang anak batita.

2. Bagi Ibu dan Batita

Diharapkan ibu bisa menambah informasi mengenai tumbuh kembang pada masa Golden Period supaya bisa memberikan pola asuh dan pemenuhan gizi yang tepat untuk anaknya sehingga tumbuh kembang anak dapat berjalan dengan baik.

3. Bagi Posyandu Desa Garajati

Diharapkan untuk melakukan penyuluhan dan edukasi untuk meningkatkan pengetahuan kader Posyandu tentang Golden Period pada tumbuh kembang anak batita.

Pengabdian Dan Pemberdayaan Masyarakat), 3(2), 351-359.

Moonik, P., Lestari, H., \& Wilar, R. (2015). Faktor-Faktor Yang Mempengaruhi Keterlambatan Perkembangan Anak Taman Kanak-Kanak. E-Clinic, 3(1).

Notoatmodjo, S., Anwar, H., Ella, N. H., \& Tri, K. (2012). Promosi Kesehatan Di Sekolah. Jakarta: Rineka Cipta, 21-23. 
JOURNAL OF MIDWIFERY CARE :

VOL. 02 No. 01, DESEMBER 2021

DOI: 10.34305/JMC.V2I01.352

Rohmah, F. N., \& Arifah, S. (2021).

Optimalisasi Peran Kader Kesehatan
Ciptaan disebarluaskan di bawah

Lisensi Creative Commons

Atribusi-NonKomersial

BerbagiSerupa 4.0 Internasional.

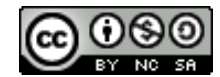

Dalam Deteksi Dini Stunting. Bemas: Jurnal Bermasyarakat, 1(2), 95-102. 